\title{
Pengaruh Fungsi Manajemen Koperasi Pondok Pesantren dan Etos Kerja Islami Terhadap Pembentukan Jiwa Wirausaha Santri di Pondok Pesantren Al-Qodiri Jember (The Influence of the Management Function of the Islamic Boarding School Cooperative and Islamic Work Ethics on the Formation of the Santri Entrepreneurial Spirit at the Al-Qodiri Islamic Boarding School, Jember)
}

\author{
Zainuri, Agus Mahardiyanto*, Ravida Mawadatur Rohmah \\ Fakultas Ekonomi dan Bisnis, Universitas Jember \\ Kabupaten Jember, Jawa Timur, Indonesia \\ Email: agusmahardianto@gmail.com
}

\begin{abstract}
Abstrak
Penelitian ini dilakukan untuk mengetahui pengaruh fungsi manajemen koperasi yang terdiri atas planning, organizing, actuating, controlling dan etos kerja Islami terhadap pembentukan jiwa wirausaha santri di Pondok Pesantren Al-Qodiri Jember. Penelitian ini tergolong dalam confirmatory research. dengan teknik analisis SEM. Populasi dalam penelitian ini adalah seluruh anggota koperasi Pondok Pesantren (Kopontren) Al-Qodiri Jember yang berjumlah 1.300 orang. Pengambilan sampel dengan prosedur teknik probability sampling dan quota sampling sehingga 150 responden terpilih sebagai sampel. Data penelitian diperoleh dari kuesioner dan wawancara kepada pengurus dan anggota Kopontren. Selanjutnya analisis dilakukan dengan menggunakan analisis SEM. Hasil menunjukkan bahwa planning, organizing, actuating, controlling dan etos kerja Islami berpengaruh signifikan langsung terhadap pembentukan jiwa wirausaha santri. Hal ini berimplikasi bahwa pentingnya untuk mengaktualisasikan fungsi-fungsi manajemen dalam setiap kegiatan dan operasional Kopontren supaya Jiwa wirausaha santri semakin terasah menjadi lebih baik. adapun planning, organizing, actuating, controlling berpengaruh signifikan tidak langsung terhadap pembentukan jiwa wirausaha santri melalui etos kerja Islami sebagai variabel intervening. Hal ini menunjukkan pentingnya memupuk etos kerja Islami para santri Kopontren Al Qodiri sebagai upaya membentuk jiwa wirausaha santri meskipun dampaknya tidak langsung.
\end{abstract}

Kata Kunci: Etos Kerja Islami, Manajemen Koperasi, Jiwa Wirausaha, Pondok Pesantren

\begin{abstract}
This research was conducted to determine the effect of the cooperative management function which consists of planning, organizing, actuating, controlling, and Islamic work ethic on the formation of the entrepreneurial spirit of the santri at the Al-Qodiri Islamic Boarding school, Jember. This research is classified as confirmatory research with SEM analysis techniques. The population in this study were all members of the Al-Qodiri Jember Islamic boarding school cooperative (Kopontren), in total of 1,300 people. Sampling using probability technique and the quota sampling technique, so that 150 respondents were selected as the research sample. Data in this research is collected using questionnaire and direct interviews with the board and Kopontren members. Furthermore, the analysis is carried out using SEM analysis. The results show that planning, organizing, actuating, controlling, and Islamic work ethics have a significant direct effect on the formation of the entrepreneurial spirit of the santri. This implies that it is important to actualize management functions in every Kopontren activity and operation so that the entrepreneurial spirit of the santri is better honed. planning, organizing, actuating, controlling have an indirect significant effect on the formation of the entrepreneurial spirit of the santri through Islamic work ethic as an intervening variable. This shows the importance of fostering the Islamic work ethic of the Al Qodiri Kopontren students as an effort to form the entrepreneurial spirit of the santri even though the impact is indirect.
\end{abstract}

Keywords: Islamic Boarding School, Cooperative Management, Entrepreneurial Spirit, Islamic Work Ethics.

\footnotetext{
${ }^{*}$ Corresponding Author
} 


\section{Pendahuluan}

Pondok pesantren merupakan lembaga pendidikan tertua di Indonesia yang bertujuan untuk mempelajari dan mengamalkan ajaran agama Islam dengan menekankan moral sebagai pedoman hidup bermasyarakat, pesantren telah bertransformasi dari awalnya lembaga yang dianggap tradisional menjadi lembaga modern dengan sentuhan nilai agamis didalamnya (Basyit, 2017). Namun, beberapa pesantren lebih memprioritaskan materi tentang agama saja, kurangnya pembekalan keahlian pada hard skill atau pun soft skill mengakibatkan lulusan pesantren seringkali membutuhkan skill tambahan saat terjun ke masyarakat. Para santripun juga akan menghadapi tantangan yang sama pada era persaingan global ini.

Kemajuan dunia usaha di indonesia mengakibatkan pentingnya pendidikan jiwa wirausaha diterapkan dipondok pesantren. Kewirausahaan merupakan proses kemampuan seseorang untuk mengamati dan menilai sebuah peluang bisnis, mengambil sebuah tindakan keuntungan dengan mengumpulkan sumber-sumber daya yang ada (Susanto, 2017). Konteks kewirausahaan tertera dalam QS. An-Nisa ayat 29. Kesuksesan pembentukan jiwa wirausaha para santri ditinjau dari pola manajemen yang ada didalamnya. Kegiatan manajemen adalah kegiatan mengelola dan mengkoordinasi suatu kegiatan untuk mencapai sebuah tujuan secara efisien dan efektif (Bacud, 2020).

Pondok pesantren Al-Qodiri Jember memiliki koperasi pondok pesantren (kopontren) yang didalamnya yang menerapkan pendidikan jiwa wirausaha kepada para santrinya. Pondok Pesantren Al-Qodiri. Beralamatkan di Jl. Manggar 139 A, Kelurahan Gebang Poreng Kecamatan Patrang Kabupaten Jember. Pendidikan wirausaha di kopontren Al-Qodiri Jember diharapkan menjadi media santri untuk melakukan praktik kerja keseimbangan antara pendidikan agama dan kewirausahaan. Koperasi merupakan sekumpulan beberapa orang secara sukarela yang membentuk sebuah badan usaha dikelola secara demokratis untuk meningkatkan kesejahteraan ekonomi anggotanya (Fathorrazi, 2010) .

Kemajuan pada dunia usaha di Indonesia mengakibatkan koperasi mengalami perkembangan jumlah yang sangat pesat dari tahun 2012-2017 (Badan Pusat Statistik, 2019). Tingkat pertumbuhan dan perkembangan koperasi yang tentunya ditinjau dari fungsi manajemenya (Ekawarna, 2010:10).

Fungsi perencanaan (planning) merupakan proses memilih dan menghubungkan fakta-fakta, penggunaan dan pembuatan asumsi-asumsi dengan cara menggambarkan dan merumuskan perkiraan apa yang diperlukan pada masa yang akan datang demi mencapai tujuan yang diinginkan organisasi (Wijaya \& Rifa'i, 2016) Fungsi perorganisasian (organizing) merupakan proses pembagian tugas dan wewenang seorang manajer yang dibantu pengelola terkait perencanaan dalam sebuah badan usaha atau koperasi (Wijayanto, 2012). Fungsi pelaksanaan (actuating) merupakan fungsi yang identik dengan penggerakan yaitu bagaimana seorang manajer dapat mengarahkan bawahanya tentang bagaimana melaksanakan tugas yang esensial dengan menciptakan kenyamanan dalam bekerjasama (Syaifullah, Titisari, \&
Puspitasari, 2019). Fungsi pengawasan (controlling) merupakan penentuan standar ukur dan supervisi pelaksanaan terhadap tujuan pencapaian organisasi (Susanto \& Susetyarsi, 2017).

Kopontren atau yang lebih dikenal dengan Koperasi pondok pesantren termasuk organisasi ekonomi berasaskan Islam-aqidah dan mendidik. Maka dari itu Selain membentuk jiwa wirausaha juga memberikan pendidikan etos kerja Islam kepada para santri. Etos kerja Islami merupakan sikap dasar yang dimiliki seseorang yaitu berupa karakter maupun kebiasaan seseorang dalam pekerjaan yang dilakukan dan mengandung sistem aqidah Islam atau kereimanan didalamnya (Yousef, 2001) (Gheitani, Imani, Seyyedamiri, \& Foroudi, 2019) (Fesharaki \& Sehhat, 2018). Terkait etos kerja Islami terdapat dalam QS. Al-Kahfi ayat 7.

Etos kerja Islami penting bagi wirausahawan untuk menyelesaikan masalah-masalah yang ada pada bisinisnya sesuai dengan syariat Islam. Adanya etos kerja Islam seorang wirausahawan tidak akan terbebani akan sebuah target pada usahanya. Oleh karena itu santri di Pondok Pesantren Al-Qodiri Jember diharapkan nantinya dapat menerapakan sikap etos kerja Islami dalam berwirausaha. Hal ini sesuai dengan salah satu misi pondok pesantren Al-Qodiri Jember yaitu mencetak manusia dengan keseimbangan trio cerdas, yakni kecerdasan intelektual, kecerdasan emosional, dan kecerdasan spiritual. Oleh karena itu peneliti ini dilakukan untuk mengetahui dan menganalisis terkait pengaruh fungsi manajemen koperasi yang terdiri atas planning, organizing, actuating, controlling dan etos kerja Islam dalam pembentukan jiwa wirausaha para santri di pondok pesantren Al- Qodiri.

\section{Kajian Teori}

Manajemen merupakan proses koordinasi pekerjaan orang lain supaya pekerjaan dapat terselesaikan secara efisien dan efektif (Fesharaki \& Sehhat, 2018). Pelaku manajemen adalah manusia dimana yang diatur oleh manusia adalah bermacam aktifitas yang timbul dalam proses manajemen berhubungan dengan faktor-faktor produksi yang disebut $6 \mathrm{M}$. Menurut Terry (2012) unsurunsur manajemen "the six $M$ in management" meliputi: Man, Money, Material, Macahine, Methods and Market. Menurut Ekawarna (2010) fungsi manajemen koperasi terdapat 4 fungsi, yaitu:

a. Fungsi Perencanaan (Planning)

Fungsi perencanaan (planning) merupakan proses memilih dan menghubungkan fakta-fakta, penggunaan dan pembuatan asumsi-asumsi dengan cara menggambarkan dan merumuskan perkiraan apa yang diperlukan di masa yang akan datang untuk pencapaian tujuan (Wijaya \& Rifa'i, 2016).

b. Fungsi Pengorganisasian (Organizing)

Fungsi perorganisasian (organizing) merupakan proses pembagian tugas dan wewenang seorang manajer yang dibantu pengelola terkait perencanaan dalam sebuah badan usaha atau koperasi. (Wijaya \& Rifa'i, 2016) 
c. Fungsi Pelaksanaan (Actuating)

Fungsi pelaksanaan (actuating) merupakan fungsi yang identik dengan penggerakan yaitu bagaimana seorang manajer dapat mengarahkan bawahannya tentang bagaimana melaksanakan tugas yang esensial dengan menciptakan kenyamanan dalam bekerjasama (Awaluddin \& Hendra, 2018).

d. Fungsi Pengewasan (Controlling)

Fungsi pengawasan (controlling) merupakan penentuan standar ukur dan supervisi pelaksanaan terhadap tujuan pencapaian organisasi (Glendoh, 2000)

Menurut Sofyan Hidayat (2016) koperasi merupakan perkumpulan yang bergabung secara suka rela membentuk badan usaha dan dikelola secara demokratis untuk meningkatkan kesejahteraan ekonomi (Sofyan Hidayat, Setiana, \& Situmeang, 2016). menurut UndangUndang koperasi tahun 1967 No.12 koperasi Indonesia adalah organisasi yang berwatak sosial, dengan beranggotakan orang atau badan hukum koperasi dengan tata susunan ekonomi sebagai usaha bersama yang berasaskan kekeluargaan yang berbasis ekonomi rakyat (Kemenkumham, 1967). Partisipasi anggota koperasi merupakan sebuah kunci keberhasilan dari usaha koperasi tersebut. Menurut Sugiharsono (2010) partisipasi memiliki 3 dimensi (Sugiharsono, 2010), yaitu

a. Partisipasi dari sifatnya

Terdapat dua macam partisipasi dari sifatnya yaitu partisipasi yang dipaksa (forced) dan partisipasi sukarela (voluntary). Partisipasi yang dipaksa (forced) merupakan partisipasi yang tidak sesuai dengan prinsip koperasi. Sedangkan partisipasi sukarela (voluntary) merupakan partispasi yang menyetujui dan mendukung adanya gagasan pada koperasi tersebut.

b. Partisipasi dari bentuknya

Terdapat dua macam partisipasi dari bentuknya yaitu partispasi formal dan partispasi informal. Formal disini merupakan telah terciptanya pengambilan dan pelaksanaan dengan mekanisme formal. Sedangkan partisipasi informal merupakan partisipasi yang hanya mendapat persetujuan lisan antara atasan dengan bawahan.

c. Partisipasi dari pelaksanaanya

Pelaksanaan partisipasi dilakukan secara langsung dan tidak langsung. Partisipasi langsung merupakan seseorang anggota dalam mengajukan sebuah aspirasi pandangan ide-idenya disampaikan secara langsung kepada pihak yang berkaitan. Sedangkan partisipasi tidak langsung merupakan partisipasi yang disampaikan atas dasar mebawa aspirasi dari orang lain

d. Partisipasi dari segi kepentinganya

Dari segi kepentingan partisipasi dibedakan menjadi partisipasi kontribusif dan partispasi insentif. Kedua partisipasi ini saling berkaitan dengan erat serta berperan ganda sebagai pemilik dan sebagai pelanggan. Pertama dalam dana pembiayaan pertumbuhan koperasi. Kedua setelah dana terkumpul selanjutnya menetapkan tujuan, kebijakan, serta pengawasan. Ketiga sebagai pelanggan harus memanfaatkan pelayanan yang tersedia di koperasi tersebut (Sugiharsono, 2010).
Kewirausahaan merupakan proses kemampuan seseorang untuk mengamati dan menilai sebuah peluang bisnis, mengambil sebuah tindakan keuntungan dengan mengumpulkan sumber-sumber daya yang ada (Saragih, 2017). pembentukan jiwa wirausaha terdapat 3 dimensi dan indikator di dalamnya, yaitu:

a. Pendidikan

Pendidikan merupakan hal yang menyangkut bagaimana seorang wirausaha dapat menjalankan perananya dengan baik. Pendidikan dapat menghasilkan seseorang trampil dan memiliki nilai intelektual. Pendidikan jasmani dan rohani perlu diterapkan keduanya guna menyeimbangkan antara kemampuan intelektual dan keterampilan.

b. Nilai Pribadi

Nilai merupakan suatu keyakinan untuk melakukan sebuah tindakan terhadap sebuah pilihanya. Dengan adanya suatu nilai akan mempentuk sifat pribadi seseorang. Nilai pribadi ini akan membentuk karakteristik seseorang dalam melakukan suatu tindakan.

c. Pengalaman kerja

Pengalaman kerja merupakan proses pembelajaran seseorang dari pendidikan formal dan non formal yang membawa yang membawa pengaruh perilaku yang lebih baik. Pengalaman kerja merupakan proses pengetahuan, keterampilan, penguasaan sesorang terhadap pekerjaan yang telah dilaksanakanya.

Menurut Ardiansyah (2019) pondok pesantren merupakan penyebaran dan pengembangan ilmu agama Islam dengan suatu pendidikan atau pengajaran pada suatu lembaga keagamaan (Ardiansyah, 2019). Pondok pesantren juga dikenal sebagai lembaga yang memiliki fokus tidak hanya dalam pengembangan pendidikan keagamaan tetapi juga sosial budaya dan juga ekonomi (Susanto, 2017).

Berdasarkan Peraturan Menteri Agama Republik Indonesia No. 30 Tahun 2020, Tentang Pondok Pesantren menyatakan bahwa Pondok pesantren merupakan lembaga pendidikan agama Islam yang diasuh oleh seorang kyai dan yayasan atau organisasi dengan sistem asrama pengajaranya dalam bentuk sekolah/ madrasah dengan masa belajar yang disesuaikan jenis tingkatan sekolah atau program kitab disesuaikan dan diselesaikan, serta menjadikan masjid sebagai puasat kegiatan". Pendidikan pondok pesantren merupakan bagian dari sistem pendidikan nasional. Ditinjau dari "Tri Dharma Pesantren", yaitu: "keimanan dan ketakwaan kepada Allah SWT, pengembangan keilmuan yang bermanfaat, dan pengabdian kepada agama, masyarakat, dan negara" (Kemenag, 2020).

Menurut Kirom (2018) etos kerja merupakan moral, komitmen, kejujuran, ketepatan waktu, kekreatifan, sebuah tanggung jawab, kuat pendirian, kreatif, dan kepercayaan diri (Kirom, 2018). Etos kerja Islam merupakan konsep etika keyakinan akan prinsip dan ajaran dalam Islam (Gheitani et al., 2019). Terdapat hadist dari Aisyah r.a., yang maknanya ialah manusia dicintai Allah bilamana ia bekerja dan melakukan sesuatu dengan cara profesional (HR. Thabrani, No: 891, Baihaqi, No: 334).

Dimensi dari etos kerja Islami dibagi menjadi tiga macam (Kirom, 2018), yaitu: 
a. Kerja Dilandasi Aqidah

Etos kerja Islam dimaknai sebagai keyakinan seorang muslim dalam bekerja bahwa kerja semata-mata untuk mendapatkan Ridha Allah yaitu niat bekerja sebagai ibadah.

b. Kerja Dilandasi Ilmu

Kerja dilandasi ilmu yang benar merupakan hal yang sangat penting. Dalam melakukan sebuah pekerjaan harus berlandaskan ilmu yaitu wahyu dari Allah SWT. Ilmu juga berdasarkan Sunatullah atau hukum alam. Jadi ilmu dalam bekerja akan mewujudkan kerja yang sesuai dengan syariah Islam.

c. Kerja yang Meneladani Sifa-sifat Ilahi dan Mengikuti Petunjuknya

Etos kerja Islam dapat dihubungkan dengan sifat Ilahiah serta mengikuti petunjuk Allah merupakan tanggung jawab keimanan seseorang terhadap ajaran Islam. Seseorang harus memanfaatkan potensi-potensi pada dirinya sekaligus meneladani sifat-sifat Ilahi dalam menjalankan kerja.

\section{Metode}

\section{Rancangan atau Desain Penelitian}

Penelitian ini ialah confirmatory research dengan tujuan untuk menjelaskan hubungan kausalitas antara variabel satu dengan variabel lain dengan pengujian hipotesis (Wagenmakers, Wetzels, Borsboom, van der Maas, \& Kievit, 2012). Pendekatan pada penelitian ini mengunakan penelitian kuantitatif, berawal dari teori kemudian dijadikan hipotesis disertai pengukuran dan operasional konsep, selanjutnya dihitung secara generalisasi empiris berstandarkan statistik yang nantinya dapat disimpulkan hasil dari penelitian.

\section{Jenis dan Sumber Data}

Data primer dari penelitian ini didapatkan dari teknik observasi, wawancara, dan kuesioner (angket). Kuesioner disusun berdasarkan penelitian terdahulu yang telah disesuaikan dengan penelitian sekarang beserta objeknya. Observasi pada penelitian ini dilakukan dengan melalui pengamatan langsung pada objek penelitian untuk memperoleh data awal mengenai gambaran umum pondok pesantren Al-Qodiri Jember. Wawancara pada penelitian ini dilakukan kepada pengurus pondok pesantren Al-Qodiri Jember untuk mendapatkan informasi langsung terkait profil pondok pesantren AlQodiri Jember. Kuesioner pada penelitian ini disebar kepada responden. Data sekunder pada penelitian ini didapatkan sudah dalam bentuk publikasi. Data sekunder pada penelitian ini diperlukan untuk mendapatkan data tentang pondok pesantren Al-Qodiri Jember.

\section{Populasi dan Sampel}

Populasi dalam penelitian ini adalah seluruh anggota koperasi pondok pesantren Al-Qodiri Jember yang berjumlah 1.300. Prosedur pengambilan sampel dengan teknik probability sampling dan teknik quota sampling dengan pengembangan model sampel yang digunakan sebanyak 100-200 sampel dengan teknik maximum likelihood examation. 150 responden dipilih sebagai sampel. Penentuan sampel pada penelitian ini awalnya 200 sampel, namun terdapat 50 sampel yang tidak memenuhi kriteria. Maka penentuan sampel dalam penelitian ini yaitu sebanyak 150 sampel dari total 1300 santri.

\section{Metode Analisis Data}

Analisis Structural Equation Modeling SEM digunakan dengan pendekatan konfirmatori sebagai teknik analisis multivariate untuk menganalisis pengaruh fungsi manajemen koperasi dan etos kerja Islam terhadap pembentukan jiwa wirausaha santri.

\section{Identifikasi Variabel Penelitian}

Variabel-variabel yang akan dianalisis dalam penelitian ini, meliputi:

a. Variabel independen

1) $\mathrm{X} 1$ : Planning

2) $\mathrm{X} 2$ : Organizing

3) $\mathrm{X} 3$ : Actuating

4) X4 : Controlling

b. Variabel dependen

Y : Pembentukan jiwa wirausaha santri

c. Variabel intervening

X5 : Etos Kerja Islami

\section{Hasil dan Pembahasan}

\section{Hasil}

1. Uji Goodness of Fit Test

Berdasarkan tabel 1 bahwa dari 8 kriteria, Chi-square menunjukan nilai yang kecil, RMSEA, CMIN/DF, CFI menunjukan fit yaitu layak, sedangkan Signifikasi, GFI, AGFI, TLI menunjukan marginal yaitu tidak layak. Kriteria diketahui bahwa kesesuaian model layak diterima apabila minimal 2 kriteria menunjukan fit atau layak. Maka, dalam penelitian ini kesesuaian model dapat diterima yang berarti terdapat kesuaian antara model dengan data.

Tabel 1. Goodness of Fit Test

\begin{tabular}{cccc}
\hline Kriteria & Nilai Cut Off & $\begin{array}{c}\text { Hasil } \\
\text { Perhitungan }\end{array}$ & Keterangan \\
\hline Chi-square & Diharapkan kecil & 172,961 & Kecil \\
Signifikasi & $\geq 0,05$ & 0,045 & Marginal \\
RMSEA & $\leq 0,08$ & 0,043 & Fit \\
GFI & $\geq 0,90$ & 0,881 & Marginal \\
AGFI & $\geq 0,90$ & 0,825 & Marginal \\
CMIN/DF & $\leq 2,00$ & 1,210 & Fit \\
TLI & $\geq 0,95$ & 0,935 & Marginal \\
CFI & $\geq 0,95$ & 0,951 & Fit \\
\hline
\end{tabular}


2. Uji Konversi Penerjemahan Diagram Jalur

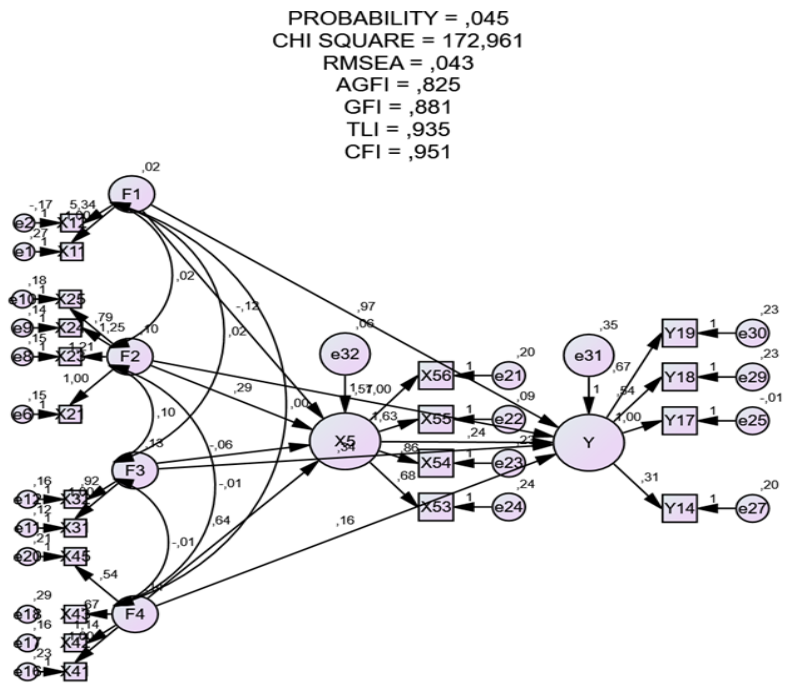

Gambar 1. Diagram Jalur

\section{Uji Kausalitas}

Tabel 2. Hasil Pengujian Kausalitas

No Variabel Koefisien CR Probabilitas Keterangan Jalur

\begin{tabular}{cccccc}
\hline 1 & Y<--- X1 & 0,97 & 2,113 & 0,035 & Signifikan \\
2 & Y<--- X2 & 0,57 & 3,827 & 0,008 & Signifikan \\
3 & Y<--- X3 & 0,34 & 1,564 & 0,003 & Signifikan \\
4 & Y<--- X4 & 0,00 & 1,536 & 0,002 & Signifikan \\
5 & Y<--- X5 & 0,24 & 2,812 & 0,017 & Signifikan \\
6 & X5<--- X1 & $-0,12$ & 1,540 & 0,009 & Signifikan \\
7 & X5<--- X2 & 0,29 & 1,735 & 0,003 & Signifikan \\
8 & X5<--- X3 & $-0,06$ & 0,169 & 0,866 & Tidak \\
& & & & & Signifikan \\
9 & X5<--- X4 & 0,64 & 3,631 & 0,001 & Signifikan \\
\hline
\end{tabular}

Berdasarkan hasil pengujian kausalitas pada tabel dan koefisien jalur pada tabel 4.19 yaitu:

1. Planning berpengaruh langsung terhadap pembentukan jiwa wirausaha santri.

Hasil analisis yang dilakukan menunjukan bahwa planning berpengaruh langsung dan signifikan terhadap pembentukan jiwa wirausaha santri. Nilai koefisien jalur positif sebesar 0,97 dengan CR sebesar 2,113>1,000 dan diperoleh signifikasi (p) 0,035< 0,05 menjadi bukti adanya pengaruh tersebut. Maka dapat disimpulkan hipotesis 1 diterima: planning berpengaruh langsung signifikan terhadap pembentukan jiwa wirausaha santri.

2. Organizing berpengaruh langsung terhadap pembentukan jiwa wirausaha santri.

Hasil analisis yang dilakukan menunjukan bahwa Organizing berpengaruh langsung signifikan terhadap pembentukan jiwa wirausaha santri. Nilai koefisien jalur positif sebesar 0,57 dengan CR sebesar 3,827 > 1,000 dan diperoleh signifikasi (p) $0,008<0,05$ menjadi bukti adanya pengaruh tersebut. Maka dapat disimpulkan hipotesis 2 diterima: organizing berpengaruh langsung signifikan terhadap pembentukan jiwa wirausaha santri.
3. Actuating berpengaruh langsung terhadap pembentukan jiwa wirausaha santri.

Hasil analisis yang dilakukan menunjukan bahwa Actuating berpengaruh langsung signifikan terhadap pembentukan jiwa wirausaha santri. Nilai koefisien jalur positif sebesar 0,34 dengan CR sebesar 1,564 > 1,000 dan diperoleh signifikasi (p) $0,003<0,05$ yang artinya terdapat pengaruh langsung. Maka dapat disimpulkan hipotesis 3 diterima: actuating berpengaruh langsung signifikan terhadap pembentukan jiwa wirausaha santri.

4. Controlling berpengaruh langsung terhadap pembentukan jiwa wirausaha santri.

Hasil uji yang dilakukan menunjukan bahwa Controlling berpengaruh langsung signifikan terhadap pembentukan jiwa wirausaha santri. Terbukti dengan koefisien jalur positif sebesar 0,00 dengan CR sebesar 1,536 > 1,000 dan diperoleh signifikasi (p) 0,002< 0,05. Maka dapat disimpulkan hipotesis 4 diterima: controlling berpengaruh langsung signifikan terhadap pembentukan jiwa wirausaha santri.

5. Etos Kerja Islami berpengaruh langsung terhadap pembentukan jiwa wirausaha santri.

Hasil uji yang dilakukan menunjukan bahwa Etos kerja Islami berpengaruh langsung signifikan terhadap pembentukan jiwa wirausaha santri. Hal ini dibuktikan dari koefisien jalur positif sebesar 0,24 dengan CR sebesar 2,812>1,000 dan diperoleh signifikasi (p) 0,017 <0,05. Maka dapat disimpulkan hipotesis 5 diterima: etos kerja Islami berpengaruh langsung signifikan terhadap pembentukan jiwa wirausaha santri.

6. Planning berpengaruh tidak langsung terhadap pembentukan jiwa wirausaha santri melalui etos kerja sebagai variabel intervening pada Pondok Pesantren Al-Qodiri Jember.

Hasil uji dalam penelitian ini menunjukan bahwa planning berpengaruh signifikan tidak langsung terhadap pembentukan jiwa wirausaha santri melalui etos kerja sebagai variabel intervening. Hal ini dibuktikan dari koefisien jalur positif sebesar $-0,12$ dengan CR sebesar 1,540>1,000 dan diperoleh signifikasi (p) $0,009<0,05$. Maka dapat disimpulkan hipotesis 6 diterima: planning berpengaruh signifikan tidak langsung terhadap pembentukan jiwa wirausaha santri melalui etos kerja sebagai variabel intervening pada Pondok Pesantren Al-Qodiri Jember.

7. Organizing berpengaruh tidak langsung terhadap pembentukan jiwa wirausaha santri melalui etos kerja sebagai variabel intervening pada Pondok Pesantren Al-Qodiri Jember.

Hasil Uji SEM menunjukan bahwa Organizing berpengaruh signifikan tidak langsung terhadap pembentukan jiwa wirausaha santri melalui etos kerja sebagai variabel intervening. Ditunjukkan oleh koefisien jalur positif sebesar 0,29 dengan CR sebesar 1,735 > 1,000 dan diperoleh signifikasi (p) $0,003<0,05$. Maka dapat disimpulkan hipotesis 7 diterima: organizing berpengaruh signifikan tidak langsung terhadap pembentukan jiwa wirausaha santri melalui etos kerja sebagai variabel intervening pada Pondok Pesantren AlQodiri Jember. 
8. Actuating berpengaruh tidak langsung terhadap pembentukan jiwa wirausaha santri melalui etos kerja sebagai variabel intervening pada Pondok Pesantren Al-Qodiri Jember

Hasil olah data menunjukan bahwa Actuating berpengaruh tidak signifikan tidak langsung terhadap pembentukan jiwa wirausaha santri melalui etos kerja sebagai variabel intervening. Hal ini dibuktikan dari koefisien jalur positif sebesar -0,06 dengan CR sebesar $0,169<1,000$ dan diperoleh signifikasi (p) 0,866> 0,05 Maka dapat disimpulkan hipotesis 8 ditolak: actuating berpengaruh tidak signifikan tidak langsung terhadapV TYGN pembentukan jiwa wirausaha santri melalui etos kerja sebagai variabel intervening pada Pondok Pesantren Al-Qodiri Jember.

9. Controlling berpengaruh tidak langsung terhadap pembentukan jiwa wirausaha santri melalui etos kerja sebagai variabel intervening pada Pondok Pesantren Al-Qodiri Jember.

Hasil dari penelitian ini menunjukan bahwa Controlling berpengaruh signifikan tidak langsung terhadap pembentukan jiwa wirausaha santri melalui etos kerja sebagai variabel intervening. Hal ini dibuktikan dari koefisien jalur positif sebesar 0,64 deengan CR sebesar 3,631>1,000 dan diperoleh signifikasi (p) 0,001<0,05. Maka dapat disimpulkan hipotesis 9 diterima: actuating berpengaruh signifikan tidak langsung terhadap pembentukan jiwa wirausaha santri melalui etos kerja sebagai variabel intervening pada Pondok Pesantren Al-Qodiri Jember.

\section{Pembahasan}

\section{Pengaruh Langsung Planning Terhadap Pembentukan Jiwa Wirausaha Santri.}

Berdasarkan hasil analisis pada hipotesis 1 menyatakan planning berpengaruh signifikan positif langsung terhadap pembentukan jiwa wirausaha santri. Pada analisis konfirmatori terdapat 2 indikator dari planning yaitu X11 dan X12 memiliki nilai valid diatas nilai yang direkomendasikan yaitu 0,45 . Pengujian validitas dan reliabilitas variabel planning memiliki nilai construct reliability sebesar sebesar 0,771336 yang berarti nilai tersebut diatas rekomendasi yaitu minimal sebesar 0,60 0,70 , maka variabel planning adalah 2 indikator valid dan reliabel.

Pengujian asumsi data bersifat multivariate normal dengan hasil pengujian normalitas menghasilkan nilai CR sebesar 1,848 diantara $-1,96 \leq \mathrm{CR} \leq 1,96(\alpha=0,05)$. Pengujian multikolinieritas dihasilkan nilai determinant of sample covariance matrix sebesar 0,000 maka dalam penelitian ini tidak terdapat adanya multikolinieritas. Hasil penelitian ini juga tidak terdapat multivariat outliers. Koefisien jalur pada variabel planning sebesar 0,97 dengan CR sebesar 2,113>1,000 dan diperoleh signifikasi (p) 0,035 < 0,05, disimpulkan bahwa planning berpengaruh signifikan langsung terhadap pembentukan jiwa wirausaha santri pada pondok pesantren Al-Qodiri Jember.

Hasil uji menunjukkan bahwa secara teoritis dan empiris menyatakan adanya hubungan fungsi manajemen berupa planning berpengaruh signifikan positif terhadap pembentukan jiwa wirausaha santri. Hasil penelitian ini diperkuat penelitian sebelumnya, yaitu pada penelitian Rofiq (2012) menyatakan bahwa terdapat pengaruh positif dan signifikan pengelolaan koperasi pondok pesantren berupa planning terhadap pembentukan jiwa wirausaha para santri anggota pon-pes Sirojuth-Tholibin Brabo, maka dari itu hipotesis tersebut diterima. Hasil penelitian ini menunjukan persamaan pada hipotesis dalam penelitian sebelumnya (Rofiq, 2012).

Hasil ini perlu dijadikan sebagai pertimbangan para pengurus Kopontren agar memiliki perencanaan baik jangka pendek maupun jangka panjang dalam pengelolaan koperasi, selain agar arah pengembangan koperasi terarah pun supaya kaderisasi santri dalam ekonomi gotong royong berupa koperasi semakin masif.

\section{Pengaruh Langsung Organizing Terhadap Pembentukan Jiwa Wirausaha Santri.}

Berdasarkan hasil dari penelitian ini pada hipotesis 2 menyatakan organizing berpengaruh signifikan positif langsung terhadap pembentukan jiwa wirausaha santri. Pada analisis konfirmatori terdapat 4 indikator dari organizing yaitu X21, X23, X24, X25 memiliki nilai valid diatas nilai yang direkomendasikan yaitu 0,45. Pengujian validitas dan reliabilitas variabel organizing memiliki nilai construct reliability sebesar 0,753917 yang berarti nilai tersebut diatas rekomendasi yaitu minimal sebesar 0,60-0,70, maka variabel organizing adalah 4 indikator valid dan reliabel.

Pengujian asumsi data bersifat multivariate normal dengan hasil pengujian normalitas menghasilkan nilai $\mathrm{CR}$ sebesar 1,848 diantara $-1,96 \leq \mathrm{CR} \leq 1,96(\alpha=0,05)$. Pengujian multikolinieritas dihasilkan nilai determinant of sample covariance matrix sebesar 0,000 maka dalam penelitian ini tidak terdapat adanya multikolinieritas. Hasil uji juga tidak terdapat multivariat outliers. Koefisien jalur pada variabel organizing sebesar 0,57 dengan CR sebesar 3,827>1,000 dan diperoleh signifikasi (p) 0,008 $<0,05$, maka dapat disimpulkan bahwa organizing berpengaruh signifikan langsung terhadap pembentukan jiwa wirausaha santri.

Hasil uji analisis membuktikan secara teoritis dan empiris menyatakan adanya hubungan fungsi manajemen berupa organizing berpengaruh signifikan positif terhadap pembentukan jiwa wirausaha santri. Hasil penelitian ini diperkuat penelitian sebelumnya, yaitu pada penelitian Rofiq (2012) menyatakan bahwa terdapat pengaruh positif dan signifikan pengelolaan koperasi pondok pesantren berupa organizing terhadap pembentukan jiwa wirausaha para santri anggota ponpes Sirojuth-Tholibin Brabo, maka dari itu hipotesis tersebut diterima. Hasil penelitian ini menunjukan persamaan pada hipotesis dalam penelitian sebelumnya (Rofiq, 2012).

Pengorganisasian menjadi salah satu instrumen penting manajemen dalam pengembangan suatu organisasi. Dalam konteks Kopontren Al Qodiri, pengorganisasian yang baik dapat dijadikan sebagai role model bagi santri dalam pengelolaan bisnis kelak saat mereka sudah menyelesaikan studi di Al Qodiri. Hal juga perlu menjadi perhatian pengelola pesantren dalam penguatan santri selain spiritual tetapi juga ekonomi (Nadzir, 2015). 


\section{Pengaruh Langsung Actuating Terhadap Pembentukan Jiwa Wirausaha Santri.}

Berdasarkan hasil dari penelitian ini pada hipotesis 3 menyatakan actuating berpengaruh signifikan positif langsung terhadap pembentukan jiwa wirausaha santri. Pada analisis konfirmatori terdapat 2 indikator dari actuating yaitu X31 dan X32 memiliki nilai valid diatas nilai yang direkomendasikan yaitu 0,45 . Pengujian validitas dan reliabilitas variabel actuating memiliki nilai construct reliability sebesar 0,630306 yang berarti nilai tersebut diatas rekomendasi yaitu minimal sebesar 0,600,70, maka variabel actuating adalah 2 indikator valid dan reliabel.

Pengujian asumsi data bersifat multivariate normal dengan hasil pengujian normalitas menghasilkan nilai $\mathrm{CR}$ sebesar 1,848 diantara $-1,96 \leq \mathrm{CR} \leq 1,96(\alpha=0,05)$. Pengujian multikolinieritas dihasilkan nilai determinant of sample covariance matrix sebesar 0,000 maka dalam penelitian ini tidak terdapat adanya multikolinieritas. Dalam penelitian ini juga tidak terdapat multivariat outliers. Koefisien jalur pada variabel actuating sebesar 0,34 dengan CR sebesar 1,564>1,000 dan diperoleh signifikasi (p) 0,003 $<0,05$, maka dapat disimpulkan bahwa actuating berpengaruh signifikan langsung terhadap pembentukan jiwa wirausaha santri.

Hasil analisis menunjukkan bahwa secara teoritis dan empiris menyatakan adanya hubungan fungsi manajemen berupa actuating berpengaruh signifikan positif terhadap pembentukan jiwa wirausaha santri. Hasil penelitian ini diperkuat penelitian sebelumnya, yaitu pada penelitian Rofiq (2012) yang menyatakan bahwa terdapat pengaruh positif dan signifikan pengelolaan koperasi pondok pesantren berupa actuating terhadap pembentukan jiwa wirausaha para santri anggota ponpes Sirojuth-Tholibin Brabo, maka dari itu hipotesis tersebut diterima. Hasil penelitian ini menunjukan persamaan pada hipotesis dalam penelitian sebelumnya (Rofiq, 2012).

Santri Kopontren Al Qodiri perlu menjadi penggerak dalm organisasi Koperasi. Dalam konteks pengembangan diri santri, Actuating menjadi pendorong santri agar mampu menjadi penggerak. dengan menjadi manajer, santri di kopontren diharapkan terasah menjadi manajer yang terampil (Susanto, 2017).

\section{Pengaruh Langsung Controlling Terhadap Pembentukan Jiwa Wirausaha Santri.}

Berdasarkan hasil dari penelitian ini pada hipotesis 4 menyatakan controlling berpengaruh signifikan positif langsung terhadap pembentukan jiwa wirausaha santri. Pada analisis konfirmatori terdapat 4 indikator dari controlling yaitu X41, X42, X43, X45 memiliki nilai valid diatas nilai yang direkomendasikan yaitu 0,45 . Pengujian validitas dan reliabilitas variabel controlling memiliki nilai construct reliability sebesar 0,647081 yang berarti nilai tersebut diatas rekomendasiyaitu minimal sebesar 0,60-0,70, maka variabel controlling adalah 4 indikator valid dan reliabel.

Pengujian asumsi data bersifat multivariate normal dengan hasil pengujian normalitas menghasilkan nilai $\mathrm{CR}$ sebesar 1,848 diantara $-1,96 \leq \mathrm{CR} \leq 1,96(\alpha=0,05)$. Pengujian multikolinieritas dihasilkan nilai determinant of sample covariance matrix sebesar 0,000 maka dalam penelitian ini tidak terdapat adanya multikolinieritas. Dalam penelitian ini juga tidak terdapat multivariat outliers. Koefisien jalur pada variabel controlling sebesar 0,00 dengan $\mathrm{CR}$ sebesar 1,536>1,000 dan diperoleh signifikasi (p) $0,002<0,05$, maka dapat disimpulkan bahwa controlling berpengaruh signifikan langsung terhadap pembentukan jiwa wirausaha santri.

Hasil uji analisis membuktikan bahwa secara teoritis dan empiris menyatakan adanya hubungan fungsi manajemen berupa controlling berpengaruh signifikan positif terhadap pembentukan jiwa wirausaha santri. Hasil penelitian ini diperkuat penelitian sebelumnya, yaitu pada penelitian Rofiq (2012) menyatakan bahwa terdapat pengaruh positif dan signifikan pengelolaan koperasi pondok pesantren berupa controlling terhadap pembentukan jiwa wirausaha para santri anggota pon-pes Sirojuth-Tholibin Brabo, maka dari itu hipotesis tersebut diterima. Hasil penelitian ini menunjukan persamaan pada hipotesis dalam penelitian sebelumnya (Rofiq, 2012).

\section{Pengaruh Langsung Etos Kerja Islami Terhadap Pembentukan Jiwa Wirausaha Santri.}

Berdasarkan hasil dari penelitian ini pada hipotesis 5 menyatakan etos kerja Islami berpengaruh signifikan positif langsung terhadap pembentukan jiwa wirausaha santri. Pada analisis konfirmatori terdapat 4 indikator dari etos kerja Islami yaitu X53, X54, X55, X56 memiliki nilai valid diatas nilai yang direkomendasikan yaitu 0,45 . Pengujian validitas dan reliabilitas variabel etos kerja Islami memiliki nilai construct reliability sebesar 1,12702 yang berarti nilai tersebut diatas rekomendasi yaitu minimal sebesar 0,60-0,70, maka variabel etos kerja Islamiadalah 4 indikator valid dan reliabel.

Pengujian asumsi data bersifat multivariate normal dengan hasil normalitas menunjukkan nilai CR sebesar 1,848 diantara $-1,96 \leq \mathrm{CR} \leq 1,96(\alpha=0,05)$. Pengujian multikolinieritas dihasilkan nilai determinant of sample covariance matrix sebesar 0,000 maka dalam penelitian ini tidak terdapat adanya multikolinieritas. Dalam penelitian ini juga tidak terdapat multivariat outliers. Koefisien jalur pada variabel etos kerja Islamisebesar 0,24 dengan CR sebesar 2,812>1,000 dan diperoleh signifikasi (p) $0,017<0,05$, maka dapat disimpulkan bahwa etos kerja Islami berpengaruh signifikan langsung terhadap pembentukan jiwa wirausaha.

Hasil penelitian ini membuktikan bahwa secara teoritis dan empiris menyatakan adanya hubungan fungsi manajemen berupa etos kerja Islami berpengaruh signifikan positif terhadap pembentukan jiwa wirausaha santri. Etos kerja Islami menjadi hal penting dalam membangun jiwa kewirausahaan dan mental santri sebagai bekal mereka di masa depan (Huda, 2016).

\section{Pengaruh Tidak Langsung Planning Terhadap Pembentukan Jiwa Wirausaha Santri Melalui Etos Kerja Islami Sebagai Variabel Intervening Pada Pondok Pesantren Al-Qodiri Jember.}

Berdasarkan uji SEM menunjukan bahwa hipotesis 6 menyatakan planning berpengaruh tidak langsung terhadap pembentukan jiwa wirausaha santri melalui etos 
kerja sebagai variabel intervening pada pondok pesantren Al-Qodiri Jember. Pada analisis konfirmatori 2 indikator planning yaitu (X11) merumuskan tujuan koperasi dan (X12) merumuskan produk barang/jasa memiliki nilai valid diatas nilai yang direkomendasikan yaitu 0,45 . Pengujian validitas dan reliabilitas variabel planning memiliki nilai construct reliability sebesar sebesar 0,771336 yang berarti nilai tersebut diatas rekomendasi yaitu minimal sebesar 0,60-0,70, maka variabel planning adalah 2 idikator valid dan reliable

Pengujian asumsi data bersifat multivariate normal dengan hasil pengujian normalitas menghasilkan nilai CR sebesar 1,848 diantara $-1,96 \leq \mathrm{CR} \leq 1,96(\alpha=0,05)$. Pengujian multikolinieritas dihasilkan nilai determinant of sample covariance matrix sebesar 0,000 maka dalam penelitian ini tidak terdapat adanya multikolinieritas. Dalam penelitian ini juga tidak terdapat multivariat outliers.

Koefisien jalur pada variabel planning sebesar 0,116 dengan CR sebesar 1,540>1,000 dan diperoleh signifikasi (p) $0,009<0,05$, maka dapat disimpulkan bahwa planning berpengaruh signifikan tidak langsung terhadap pembentukan jiwa wirausaha santri melalui etos kerja sebagai variabel intervening pada Pondok Pesantren Al-Qodiri Jember. Variabel Planning berpengaruh signifikan tidak langsung terhadap pembentukan jiwa wirausaha santri melalui etos kerja sebagai variabel intervening pada Pondok Pesantren Al-Qodiri Jember, Hasil hipotesis 6 diterima.

\section{Pengaruh Tidak Langsung Organizing Terhadap Pembentukan Jiwa Wirausaha Santri Melalui Etos Kerja Islami Sebagai Variabel Intervening Pada Pondok Pesantren Al-Qodiri Jember.}

Berdasarkan hasil dari penelitian ini menunjukan bahwa hipotesis 7 menyatakan organizing berpengaruh tidak langsung terhadap pembentukan jiwa wirausaha santri melalui etos kerja sebagai variabel intervening pada pondok pesantren Al-Qodiri Jember. Pada analisis konfirmatori terdapat 4 indikator organizing yaitu (X21) membagi tugas (X23) merumuskan struktur organisasi unit usaha (X24) menciptakan hubungan yang harmonis sesama penggurus (X25) rapat koordinasi memiliki nilai valid diatas nilai yang direkomendasikan yaitu 0,45 . Pengujian validitas dan reliabilitas variabel organizing memiliki nilai construct reliability sebesar 0,753917 yang berarti nilai tersebut diatas rekomendasi yaitu minimal sebesar 0,60-0,70, maka variabel organizing adalah 4 indikator valid dan reliabel.

Pengujian asumsi data bersifat multivariate normal dengan hasil pengujian normalitas menghasilkan nilai CR sebesar 1,848 diantara $-1,96 \leq \mathrm{CR} \leq 1,96(\alpha=0,05)$. Pengujian multikolinieritas dihasilkan nilai determinant of sample covariance matrix sebesar 0,000 artinya tidak terdapat adanya multikolinieritas. Dalam penelitian ini juga tidak terdapat multivariat outliers.

Koefisien jalur pada variabel organizing sebesar 0,228 dengan CR sebesar 1,735>1,000 dan diperoleh signifikasi (p) $0,003<0,05$, maka dapat disimpulkan bahwa organizing berpengaruh signifikan tidak langsung terhadap pembentukan jiwa wirausaha santri melalui etos kerja sebagai variabel intervening pada Pondok Pesantren Al-Qodiri Jember. Variabel organizing berpengaruh signifikan tidak langsung terhadap pembentukan jiwa wirausaha santri melalui etos kerja sebagai variabel intervening pada Pondok Pesantren Al-Qodiri Jember, Hasil hipotesis 7 diterima.

\section{Pengaruh Tidak Langsung Actuating Terhadap Pembentukan Jiwa Wirausaha Santri Melalui Etos Kerja Islami Sebagai Variabel Intervening Pada Pondok Pesantren Al-Qodiri Jember.}

Berdasarkan hasil dari penelitian ini menunjukan bahwa hipotesis 8 menyatakan actuating berpengaruh tidak langsung terhadap pembentukan jiwa wirausaha santri melalui etos kerja sebagai variabel intervening pada pondok pesantren Al-Qodiri Jember. Pada analisis konfirmatori terdapat 2 indikator yaitu (X31) melakukan koordinasi (X32) memberikan pelayanan kepada kosumen actuating memiliki nilai valid diatas nilai yang direkomendasikan yaitu 0,45 . Pengujian validitas dan reliabilitas variabel actuating memiliki nilai construct reliability sebesar 0,630306 yang berarti nilai tersebut diatas rekomendasi yaitu minimal sebesar 0,60-0,70, maka variabel actuating adalah 2 indikator valid dan reliabel.

Pengujian asumsi data bersifat multivariate normal dengan hasil pengujian normalitas menghasilkan nilai CR sebesar 1,848 diantara $-1,96 \leq \mathrm{CR} \leq 1,96(\alpha=0,05)$. Pengujian multikolinieritas dihasilkan nilai determinant of sample covariance matrix sebesar 0,000 maka dalam penelitian ini tidak terdapat adanya multikolinieritas. Hasil ini juga menunjukkan tidak terdapat multivariat outliers.

Koefisien jalur pada variabel actuating sebesar 0,061 dengan CR sebesar $0,169<1,000$ dan diperoleh signifikasi (p) 0,866 >0,05, maka dapat disimpulkan bahwa actuating berpengaruh signifikan tidak langsung terhadap pembentukan jiwa wirausaha santri melalui etos kerja sebagai variabel intervening pada Pondok Pesantren Al-Qodiri Jember. Variabel actuating berpengaruh tidak signifikan tidak langsung terhadap pembentukan jiwa wirausaha santri melalui etos kerja sebagai variabel intervening pada Pondok Pesantren Al-Qodiri Jember. Hasil hipotesis 8 ditolak.

Penolakan hipotesis 8 menunjukan bahwa pembentukan jiwa wirausaha tidak berpengaruh langsung terhadap variabel actuating melalui etos kerja Islami sebagai variabel intervening di Pondok Pesantren Al-Qodiri Jember. Actuating merupakan proses yang identik dengan penggerakan yaitu bagaimana seorang manajer dapat mengarahkan bawahanya tentang bagaimana melaksanakan tugas yang esensial dengan menciptakan kenyamanan dalam bekerjasama (Awaluddin \& Hendra, 2018). Pada penelitian ini variabel actuating diukur menggunakan 2 variabel yang sudah valid dan reliabel yaitu melakukan koordinasi dan memberikan pelayanan kepada konsumen.

Hasil penelitian ini secara teoritis, 2 indikator yaitu melakukan koordinasi dan memberikan pelayanan kepada konsumen belum mampu mencakup keseluruhan variabel etos kerja Islami dan fungsi dari manajemen koperasi 
yaitu actuating. Hasil penelitian secara empiris yaitu $C R$ dan Probability juga belum memenuhi kriteria, sehingga menunjukan hasil yang tidak signifikan. Pembentukan jiwa wirausaha santri melalui etos kerja Islami sebagai variabel intervening tidak bisa dilakukan menggunakan 2 indikator dari actuating yaitu melakukan koordinasi dan memberikan pelayanan kepada konsumen.

\section{Pengaruh Tidak Langsung Controlling Terhadap Pembentukan Jiwa Wirausaha Santri Melalui Etos Kerja Islami Sebagai Variabel Intervening Pada Pondok Pesantren Al-Qodiri Jember.}

Berdasarkan hasil dari penelitian ini menunjukan bahwa hipotesis 9 menyatakan controlling berpengaruh tidak langsung terhadap pembentukan jiwa wirausaha santri melalui etos kerja sebagai variabel intervening pada pondok pesantren Al-Qodiri Jember. Pada analisis konfirmatori terdapat 4 indikator controlling yaitu (X411) mngawasi tugas atau pekerjaan (X42) mengawasi keluar masuk anggaran/budget (X43) melakukan tugasnya dengan tanggungjawab (X45) melakukan evaluasi yaitu 0,45 . Pengujian validitas dan reliabilitas variabel controlling memiliki nilai construct reliability sebesar 0,647081 yang berarti nilai tersebut diatas rekomendasi yaitu minimal sebesar 0,60-0,70, maka variabel controlling adalah 4 indikator valid dan reliabel.

Pengujian asumsi data bersifat multivariate normal dengan hasil uji normalitas menghasilkan nilai CR sebesar 1,848 diantara $-1,96 \leq \mathrm{CR} \leq 1,96(\alpha=0,05)$. Pengujian multikolinieritas dihasilkan nilai determinant of sample covariance matrix sebesar 0,000 artinya tidak terdapat adanya multikolinieritas. Dalam penelitian ini juga tidak terdapat multivariat outliers.

Koefisien jalur pada variabel controlling sebesar 0,642 dengan CR sebesar 3,631>1,000 menunjukkan signifikansi (p) $0,001<0,05$, maka dapat disimpulkan bahwa controlling berpengaruh signifikan tidak langsung terhadap pembentukan jiwa wirausaha santri melalui etos kerja sebagai variabel intervening pada Pondok Pesantren Al-Qodiri Jember. Variabel controlling berpengaruh signifikan tidak langsung terhadap pembentukan jiwa wirausaha santri melalui etos kerja sebagai variabel intervening pada Pondok Pesantren Al-Qodiri Jember, Hasil hipotesis 9 diterima.

\section{Simpulan dan Implikasi Penelitian}

Hasil analisis data dan pembahasan pengaruh fungsi manajemen koperasi (X1), (X2), (X3), (X4)) dan (X5) terhadap pembentukan jiwa wirausaha santri (Y) maka dapat diambil beberapa kesimpulan, berikut ini:

1. Planning berpengaruh signifikan langsung terhadap pembentukan jiwa wirausaha santri.

2. Organizing berpengaruh signifikan langsung terhadap pembentukan jiwa wirausaha santri.

3. Actuating berpengaruh signifikan langsung terhadap pembentukan jiwa wirausaha santri.

4. Controlling berpengaruh signifikan langsung terhadap pembentukan jiwa wirausaha santri.

5. Etos kerja Islami berpengaruh signifikan langsung terhadap pembentukan jiwa wirausaha santri.
6. Planning berpengaruh signifikan tidak langsung terhadap pembentukan jiwa wirausaha santri melalui Etos Kerja Islami sebagai variabel intervening pada Pondok Pesantren Al-Qodiri Jember.

7. Organizing berpengaruh signifikan tidak langsung terhadap pembentukan jiwa wirausaha santri melalui Etos Kerja Islami sebagai variabel intervening pada Pondok Pesantren Al-Qodiri Jember.

8. Actuating berpengaruh tidak signifikan tidak langsung terhadap pembentukan jiwa wirausaha santri melalui Etos Kerja Islami sebagai variabel intervening pada Pondok Pesantren Al-Qodiri Jember.

9. Controlling berpengaruh signifikan tidak langsung terhadap pembentukan jiwa wirausaha santri melalui Etos Kerja Islami sebagai variabel intervening pada Pondok Pesantren Al-Qodiri Jember.

\section{Ucapan Terima Kasih}

Terimakasih kepada Pengasuh dan Pengurus Koperasi Pondok Pesantren (Kopontren) Al Qodiri Jember atas waktu dan kesediaannya sehingga penelitian ini dapat terselesaikan.

\section{Referensi}

Ardiansyah, D. H. . (2019). Strategi Pesantren Dalam Mengembangkan Multitalenta Santri Melalui Kegiatan Muhadharah. Universitas Islam Negeri Sunan Ampel Surabaya. Retrieved from http://digilib.uinsby.ac.id/35312/3/M. Dafiq Ardiansyah_F52317373.pdf

Awaluddin, \& Hendra. (2018). Fungsi Manajemen Dalam Pengadaan Infrastruktur Pertanian Masyarakat di Desa Watatu Kecamatan Banawa Selatan Kabupaten Donggala. Publication, 2(1).

Bacud, S. A. D. (2020). Henri fayol's principles of management and its effect to organizational leadership and governance. Journal of Critical Reviews, 7(11), 162-167. https://doi.org/10.31838/jcr.07.11.25

Basyit, A. (2017). Pembaharuan Model Pesantren: Respon Terhadap Modernitas. KORDINAT, XVI(2).

Fathorrazi, M. (2010). Strategi Tebang Pilih sebagai Alternatif Pengembangan Koperasi di Kabupaten Jember. Jurnal Sosial Ekonomi Pertanian, 4(2).

Fesharaki, F., \& Sehhat, S. (2018). Islamic human resource management (iHRM) enhancing organizational justice and employees' commitment: Case of a Qard al-Hasan bank in Iran. Journal of Islamic Marketing, 9(1), 204-218. https://doi.org/10.1108/JIMA-03-2017-0029

Gheitani, A., Imani, S., Seyyedamiri, N., \& Foroudi, P. (2019). Mediating effect of intrinsic motivation on the relationship between Islamic work ethic, job satisfaction, and organizational commitment in banking sector. International Journal of Islamic and Middle Eastern Finance and Management, 12(1), 76-95. https://doi.org/10.1108/IMEFM-012018-0029

Glendoh, H. S. (2000). Fungsi Pengawasan dalam 
Penyelenggaraan Manajemen Korporasi (Sentot Harman Glendoh) Fungsi Pengawasan dalam Penyelenggaraan Manajemen Korporasi. Jurnal Manajemen Dan Kewirausahaan, 2(1). Retrieved from http://puslit.petra.ac.id/journals/management/

Huda, C. (2016). Etos Kerja Pengusaha Muslim (Studi Kasus pada Pengusaha Muslim Alumni UIN Walisongo Semarang). Economica, VII(2).

Kemenag. Peraturan Menteri Agama Nomor 30 Tahun 2020 tentang Pendirian dan Penyelenggaraan Pesantren, Pub. L. No. 6251, Menteri Agama (2020). Indonesia: Kemenag.

Kemenkumham. Undang-Undang Republik Indonesia No.12 Tahun 1967, Negara Republik Indonesia § (1967). Indonesia.

Kirom, C. (2018). Etos Kerja dalam Islam. Tawazun: Journal of Sharia Economic Law, 1(1). Retrieved from http://journal.stainkudus.ac.id/index.php/tawazun/in $\operatorname{dex}$

Nadzir, M. (2015). Membangun Pemberdayaan Ekonomi di Pesantren. Economica: Jurnal Pemikiran Dan Penelitian Ekonomi Islam, VI(1), 37.

Rofiq, A. (2012). Pembaharuan Pesantren: Respon Terhadap Tuntutan Transformasi Global. STAIN Jember, Jember.

Saragih, R. (2017). Membangun Usaha Kreatif, Inovatif dan Bermanfaat Melalui Penerapan Kewirausahaan Sosial. Jurnal Kewirausahaan, 3(DESEMBER). Retrieved from http://jklmii.org

Sofyan Hidayat, O., Setiana, E., \& Situmeang, C. (2016). Pengembangan Sistem dan Penguatan Manajemen Koperasi. Jurnal Pengabdian Kepada Masyarakat, 22(4).

Sudarsono. (2018). Pendidikan Ibadah Perspektif AlQur'an dan Hadits. CENDEKIA: Jurnal Studi KeIslaman, 4(1).
Sugiharsono. (2010). Pentingnya Partisipasi Anggota Dalam Mendukung Keberhasilan Usaha Koperasi. INFORMASI, $36(1)$. https://doi.org/10.21831/informasi.v1i1.5667

Susanto, D. (2017). Manajemen Pengembangan Sumber Daya Santri Berbasis Teknologi Tepat Guna Di Pondok Pesantren (Perspektif Dakwah). Jurnal Ilmu Dakwah, 37(2).

Susanto, A. B., \& Susetyarsi, T. (2017). Journal of Management and Markeing Review Job Satisfaction and Absenteeism on the Performance of Lecturer in Private Higher Education in Semarang. J. Mgt. Mkt. Review, 2(2), 14-19. Retrieved from www.gatrenterprise.com/GATRJournals/index.html

Syaifullah, I. I., Titisari, P., \& Puspitasari, N. (2019). Work Satisfaction In Compensation Mediation and Motivation on Productivity Permanent Employees of Pt. Sinergi Mitra Utama in Bandung. International Journal of Scientific Research and Management, 7(03). https://doi.org/10.18535/ijsrm/v7i3.em01

Wagenmakers, E. J., Wetzels, R., Borsboom, D., van der Maas, H. L. J., \& Kievit, R. A. (2012). An Agenda for Purely Confirmatory Research. Perspectives on Psychological Science, 7(6), 632-638. https://doi.org/10.1177/1745691612463078

Wijaya, C., \& Rifa'i, M. (2016). DASAR-DASAR MANAJEMEN: Mengoptimalkan Pengelolaan Organisasi Secara Efektif dan Efesien. (S. Saleh, Ed.) (Vol. 1). Medan: Perdana Publishing.

Yousef, D. A. (2001). Islamic work ethic A moderator between organizational commitment and job satisfaction in a cross-cultural context. Personnel Review (Vol. 30). \# MCB University Press. Retrieved from http://www.emerald-library.com/ft 